doi: $10.18575 / \mathrm{msrs} . s m . e .17 .17$

UDC 616.155.392-085

COBISS.RS-ID 6835224

\title{
The Importance of the Flow Cytometry for the Diagnostics of the Chronic Lymphoproliferative Diseases
}

\begin{abstract}
Introduction: Mature B cell neoplasms comprise over $90 \%$ of lymphoid neoplasms worldwide and $4 \%$ new cancers every year. Together with morphology, flow cytometry immunophenotyping is essential for the diagnosis of these diseases.
\end{abstract}

Aim of the Study: The aim of this study was to examine concordance of working diagnosis with immunophenotyping results in patients with suspicion on mature $B$ cell neoplasm.

Patients and Methods: The examination included 125 patients, divided in 3 groups on diagnosis founded by haematologist: CLL, NHL and other (descriptive diagnosis). Sample was K2EDTA peripheral blood, diluted with phosphate buffer and incubated with appropriate combination of fluorochrome conjugated monoclonal antibodies .4-color antibody panel for B chronic lymphoproliferation was applied. Analysis performed on FACS Canto II flow cytometer, DIVA software.

Results: In the first 2 groups, $72.9 \%$ immunophenotypization were in concordance with working diagnosis. 19.8\% would have been misclassified without immunophenotypization, $7.3 \%$ were recommended for the further examination. In the group „other“, diagnosis couldn't have been established without immunophenotypization. 12 samples were not chronic B lymphoproliferative diseases, and 8 had normal B cell immunophenotype.

Conclusion: In some patients, clinical features and cell morphology are not specific for the disease and thus insufficient for the diagnostic conclusion. By using flow cytometry, misclassification and inadequate therapy was prevented for significant number of patients and diagnosis established for those with descriptive diagnosis. Panel for chronic lymphoproliferative diseases is also useful for differential diagnostic exclusion of chronic lymphoproliferative disease and pointing towards specified direction, e.g. acute leucosis, T, B, NK lymphoproliferative disorders or to confirm normal B cell phenotype.

Key words: flow cytometry, immunophenotype, monoclonal antibody panel, B chronic lymphoproliferative diseases

(Scr Med 2017:48:120-125)

\section{Nataša Lazićc}

${ }^{1}$ Institute of Clinical Laboratory Diagnostics, University Clinical Center of the Republic of Srpska, Banja Luka

\section{Contact address:}

Nataša Lazić

Institute of Clinical Laboratory

Diagnostics,

University Clinical Center of the Republic of Srpska,

Street address: NN 12 beba

78 ooo Banjaluka

Republic of Srpska

Bosnia i Herzegovina e-mail:

natasa.lazic@kc-bl.com

phone number: +387-51-342-171
Submitted: September $4^{\text {th }}, 2017$ Accepted: September $16^{\text {th }}, 2017$ 


\section{Introduction}

In the modern diagnostics, the flow cytometry takes an important place as one of the basic and irreplaceable tools for diagnostics, classification, monitoring and prediction of the malignant hematological diseases. The extreme complexity of these diseases on one side, and availability of the different therapeutic protocols for the different types of these diseases on the other side, made the accurate and precise diagnosing the imperative. Contribution to this is made by the fact that the World Health Organization in the Classification of Tumours of Haemopoietic and Lymphoid Tissues suggests multiparametric approach in diagnosis of these diseases, and basic parameter, besides the detailed history of the disease and the clinical examination, are morphological, immunophenotypic and genetic research for each entity of the disease. ${ }^{1}$ The clinical picture and cell morphology itself, as well known and applied means of research, are insufficient in many cases, quite often due to the similar clinical presentation and cell morphology, it is not possible to draw a diagnostic conclusion based on these finding or, in some cases, it results to be wrong diagnosis. Besides serious, sometimes even fatal consequences for the patients, such approach has got the negative consequences on the health care system due to increase in the expenses of the medical care caused by the diagnostic insufficiency.

Immunophenotypization by the flow cytometry enables the examination of the phenotype of the separate cells in the suspension and summarizing the results which gives data about the presence or absence of antigen expression as well as the expression intensity. Observed globally, there is given the immunophenotypic cell pattern on the population of interest for the observed disease. Meanwhile, there are no separate antigens specific for the particular disease. Instead, their mutual relation is observed and analyzed which makes the analysis of the flow cytometry very demanding and complex, but in a great number of cases, very useful and precise due to the huge number of data that are able to be obtained from the cells. Therefore, the flow cytometry is helpful in determining the cell line, the degree of the cell maturity, abnormal patterns of the expression and detailed immunophenotype of the pathological cell population. From all the above mentioned, the diagnostic conclusion is drawn if there is a phenotype characteristic for some disease. In the cases of the atypical phenotype, the disease is assigned to the appropriate group and additional examinations should be done due to the precise diagnostics (immunohistochemical, FISH, molecular researches).

B mature lymphoproliferations make the most of the malignant blood diseases, and according to the
WHO data, they represent 90\% of the total lymphoid malignancies. They also present $4 \%$ of the newly discovered carcinomas a year. Immunophenotypisation in diagnostics of $\mathrm{B}$ chronic lymphoproliferative diseases is an irreplaceable method and together with morphology, it presents the essential search that should be undertaken in the diagnostics of these diseases. ${ }^{1}$ Based on the finding of the immunophenotypisation, it is possible to discover aberrant expression patterns and establish the phenotypic characteristics related to particular diseases. Applying of the score system as the additional tool in diagnosing of these diseases is the result of need for some standardization and quantification in diagnostic of B chronic lymphoproliferative diseases. In order to increase the preciseness of the score system, the different studies with the different CD markers in this system are taken. $^{2-4}$ The most common score system has got $0-5$ points and it includes $\mathrm{CD}_{5}, \mathrm{CD} 23, \mathrm{FMC}_{7}, \mathrm{CD} 79 \mathrm{~b}$ and surface immunoglobulin chains and its preciseness is $96.6 \%$ if cut off of three points is used. ${ }^{2}$

In most cases of the chronic lymphocytic leukemia (CLL), cell morphology is characteristic and typical for this disease. However, in a number of cases, flow cytometry has a huge and diagnostic decisive significance.

The chronic lymphatic leukemia has got the most morphological and immunophenotipyc similarities with the Mantle cell lymphoma (MCL). Due to their partial overlapping, this type of lymphoma is mostly considered in the differential diagnostics of the chronic lymphocytic leukemia. Due to the different therapeutic approach and prediction of the diseases, their diagnostic differentiation is very important. For that purpose, it is recommended Cyclin D1 testing. „Cyclin D1 is not only implicated in tumor genesis of Mantle cell lymphoma, but also in progression and extension of the disease when expressed in high levels (50\% cut off value) and it seems to have prognostic impact in MCL“. 5

As it is already known, the malignant cell of B lineage in the most cases imitates the normal B cells stopped at the certain maturity level. The classification of this disease group is mostly done based on this fact. On the opposite side, at the hairy cell leukemia (HCL), the cells do not match any stage of the development of the normal lymphoid cells. Morphologically typical cells have got their own hairy scions, which are sometimes difficult to find in the peripheral blood smear, and in some cases they are even invisible. Because of that and very characteristic immunophenotype, using the flow cytometry, this disease can be clearly differentiated from the other that are differential diagnostically considered, so the flow cytometry is essential for HCL diagnoses. ${ }^{6}$ 


\section{Aim of the Study}

The aim of the study was to present the results of the Laboratory for the flow cytometry in the University Clinical Centre of the Republic of Srpska during three years with the special review on the structure of the referential diagnosis, the degree of concordance between the referential diagnosis and the diagnosis resulted from the analysis of the immunophenotype by applying the method of the flow cytometry and the possibility of setting the final diagnosis for the patients who were suspected to have had chronic lymphoproliferative diseases.

\section{Patients and Methods}

The examination included 125 patients. The laboratory had an antibody panel for B chronic lymphoproliferative diseases. Therefore, the indications for receiving patients for immunophenotyping by the flow cytometry were chronic lymphocytic leukemia (CLL), B non Hodgkin lymphoma (B-NHL) with dissemination in peripheral blood, Hairy cell leukemia (HCL), or the suspicion on the mentioned diseases. The patients were divided into three groups according to the referential diagnosis: CLL, B-NHL and the "others", a category with the general and descriptive diagnoses and the ones where lymphoproliferative diseases should have been differentially diagnostically excluded.

The sample for the research was peripheral blood with K2EDTA. It was diluted by the phosphate buffer in order to have a billion of the leukocytes in $100 \mu$ l. An appropriate volume of monoclonal antibodies in certain combinations was pipetted in each tube, added $100 \mu$ l of the diluted sample, mixed to a vortex centrifuge and incubated for 20 minutes at room temperature in the dark. It was then lysed using FACS Lysing (BD) solution, washed with phosphate buffer, and fixed by CellFIX solution.

A 4-colour panel of monoclonal antibodies (antibodies conjugated with fluorochromes FITC, PE, PerCPCy5.5, APC) from BD Pharmingen and BD Biosciences were applied. The panel included testing of 18 antibodies in appropriate combinations (CD19, CD3, CD5, CD3, CD23, CD43, CD79b, FMC7, Kappa, Lambda, IgG, IgM, IgD, CD103, CD10, CD138). In the cases where it was necessary, CD45, CD34 and CD117 were used, in order to differentially diagnostically exclude the acute leukemia. When there was a suspicious of HCL, CD103, CD25, CD11c were added. As a negative control, Mouse Ig of the class IgG1 was conjugated by appropriate fluorochrome. Gating strategy was $\mathrm{FSC}^{\mathrm{low}} / \mathrm{SSCl}{ }^{\text {low }}$ for lymphocytes, and CD19 + / SSC low for B lymphocytes, while CD19 was used as the gating marker in all the combinations. The analysis was performed on the flow cytometer FACS Canto TM II (BD biosciences, San Jose, California, USA) and DIVA software. The quadrant gate was set so that the control sample cells were located in the lower left quadrant. Cut off for marker positivity was defined in $30 \%$ of cells above the control result. The expression intensity was determined on the logarithmic scale as weak, medium, and high (low, med, high) and compared with expression patterns in normal, healthy cells. A score system of 5 points was applied which included CD5, CD23, CD79b, FMC7 and superficial light immunoglobulin chains. ${ }^{1.5}$

\section{Results}

In this study, the patients were classified according to the referential diagnosis into three groups, so there were 83 samples in the first group, 13 samples in the second, and in the third one, there were 25 samples. By applying the score system, 69 samples had a score of four and five, 23 had zero, one and two points, 10 samples were with three points. Most samples, whose immunophenotype corresponded to CLL, had a score of four and five points, which matched the literature data, while those with a phenotype characteristic of the NHL had a score of zero and one point. „Application of the scoring system to all the cases showed that $87 \%$ of CLL scored 5 and 4 and only $0.4 \%$ scored o or 1 , whereas $89 \%$ of other B-cell leukemias and $72 \%$ of lymphomas scored o or 1 ; only one case (0.3\%) scored 4 and none scored 5 “. 5 The results showed that a definitive diagnosis was found in 102 cases (84.3\%) by flow cytometry, and further examinations were recommended for 19 patients (15.7\%). Most samples were diagnosed with CLL (83 samples). At 64 samples, the diagnosis was confirmed. Mostly it was not possible to distinguish between CLL and MCL, so they were referred to the Cyclin D1 test for differential diagnostic clarification. Eight samples were found not to have belonged to the group of chronic, and due to the presence of a significant percentage of blast (from 10-60\%) they were referred for examination by the panel for acute leukemia. Eight samples had a normal finding (Table 1).

The second group included a small number of patients, insufficient to make specific conclusions about the immunophenotyping of NHL. A significant number of samples were included in the category “other" (Figure 1).

The samples in the third group showed the greatest diversity of the results obtained by flow cytometry, which is understandable, since there were samples that could not have been classified in a particular category based on the clinical finding but came under general diagnoses such as leucosis, lymphocytosis, sy. lymphoproliferativum. In nine samples, with working diagnosis of pancytopenia or splenomegalia, there was a suspicion of HCL. In two cases it was confirmed that it was HCL. 
The largest number of samples had immunophenotypic characteristics of mature B lymphoproliferative diseases, but some of the samples did not belong to this group of diseases (Figure 2).

Table 1. Presentation of Findings of the Immunophenotyping of Chronic Lymphoproliferative Diseases According to the Relation of the Referential Diagnosis and Immunophenotypization Results

\begin{tabular}{ccccc}
\hline $\begin{array}{c}\text { Immunophe- } \\
\text { notypisation } \\
\text { finding }\end{array}$ & CLL & NHL & Other & Total \\
CLL & 64 & 4 & 2 & $\mathbf{7 0}$ \\
NHL & 10 & 6 & 6 & $\mathbf{2 2}$ \\
HCL & $/$ & $/$ & 2 & $\mathbf{2}$ \\
Panel for acute & 2 & 1 & 5 & $\mathbf{8}$ \\
leucosis & 1 & 0 & 2 & $\mathbf{3}$ \\
\hline $\begin{array}{c}\text { Panel za T cells } \\
\text { Panel za NK cells }\end{array}$ & 0 & 0 & 1 & $\mathbf{1}$ \\
CLL vs. MCL & 5 & 2 & 0 & $\mathbf{7}$ \\
\hline Normal & 1 & 0 & 7 & $\mathbf{8}$ \\
\hline Total & $\mathbf{8 3}$ & $\mathbf{1 3}$ & $\mathbf{2 5}$ & $\mathbf{1 2 1}$ \\
\hline
\end{tabular}

Figure 1. Structure of the Referential Diagnosis Shown as Number and Percentage

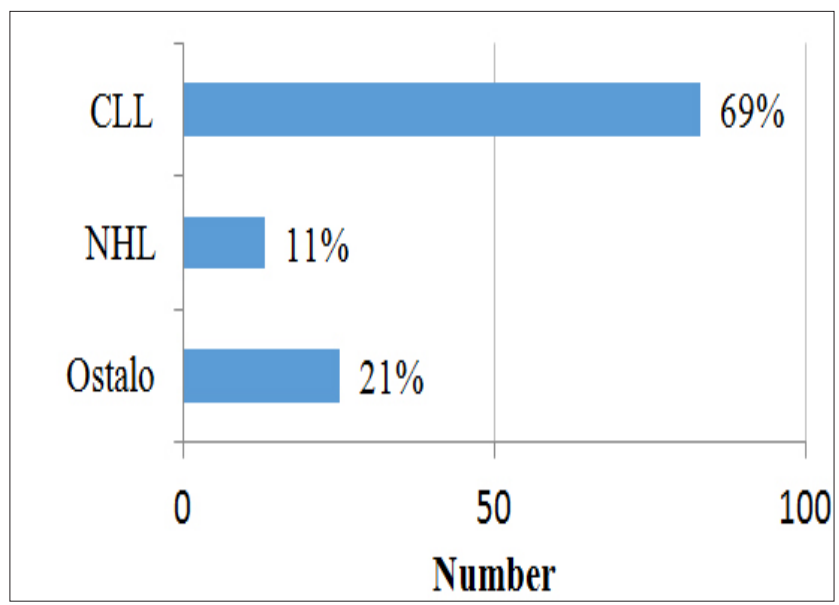

Figure 2. Results of Immunophenotyping by Flow Cytometry Shown as Number and Percentage

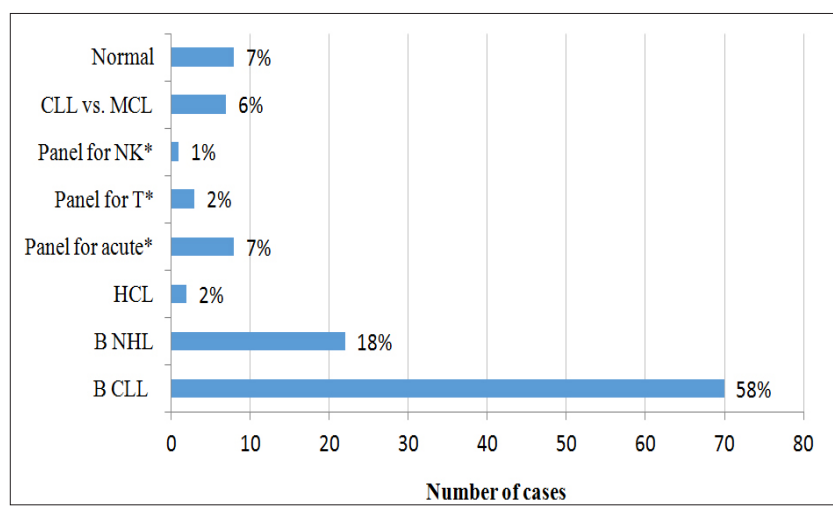

Recommended testeting with other antibody panels

Five samples were received for processing in order to differentially diagnostically exclude the chronic lymphoproliferation. The use of chronic lymphoproliferative panels for this purpose was not rational. Besides, there were six samples that were not referred according to the instructions on indications given by the laboratory considering the antibody panel, samples of patients who had been on corticosteroid therapy, as well as those with no previous diagnostic procedure performed. These are, of course, situations that should be minimized, in order to avoid unnecessary sampling and unjustified costs. For the above mentioned reasons, four samples were not taken for the analysis.

Without the flow cytometry, in $19.8 \%$ patients, diagnosis would have been incorrect, and for $7.3 \%$, a further examination was proposed to confirm the diagnosis. The patients from the group "others", where the diagnosis could not have been found without flow cytometry, were not taken into account (Figure 3).

Figure 3. Compliance of the Results of Immunofenotyping with the Referential Diagnosis

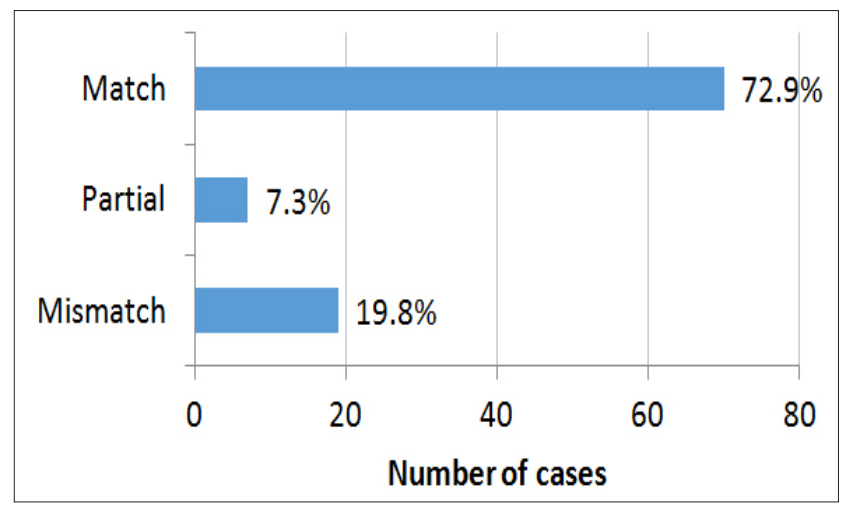




\section{Discussion}

CLL is the most common leukemia in adult patients. According to the WHO data, the incidence of this disease is 2-6 cases per 100000 people per year. Its frequency increases with age and reaches 12.8/100000 at the age of 65. It represents the largest number of chronic lymphoproliferative disorders, and according to our data, $58 \%$ of the samples are sent to the immunophenotyping laboratory. It should be considered that the real percentage is higher, because some of the patients with evident CLL are not additionally diagnosed with the usage of this method. If we compare the literature data which say that $15 \%$ of cases of CLL have atypical morphology and that without the use of flow cytometry, they cannot be properly classified, with our data, it is obvious that there is the approximate result. However, when we include the third group in consideration, the samples that came under the descriptive diagnosis, then our data show a greater deviation than the data found in the literature. One of the reasons is non-compliance of the instructions given by the laboratory regarding the panel antibodies we have. It is interesting that we found a number of patients with normal immunophenotype and patients with a high percentage of blast in the peripheral blood, wrongly classified in a group of chronic lymphoproliferative disorders before the flow cytometric examination was conducted.

The largest immunophenotypic similarity exists between CLL and MCL, ${ }^{6}$ as shown by our data. HCL, which is a rare disease and presents $2 \%$ of lymphoid leukemia, and is characterized by a typical immunophenotype pattern, ${ }^{7,8}$ was established in 2 patients. A number of patients were not diagnosed and were recommended for further examination, referring to acute, $\mathrm{T}$ and $\mathrm{NK}$ chronic lymphoproliferations (10\%). The laboratory did not have antibodies for these diseases, so the study was limited to the antibody panel for B chronic lymphoproliferations. Therefore, comparison of some data with literature data is difficult or incomplete..$^{9-11}$

\section{Conclusion}

In this study, the significance and necessity of immunophenotyping by flow cytometry for the diagnosis of chronic lymphoproliferative disorders were pointed out. Using this method, the wrong classification was avoided, and therefore inadequate treatment for a significant number of patients, and a diagnosis for patients referred to descriptive, working diagnoses were set. In a number of patients, using a classic diagnosis based on anamnesis, clinical examination, and morphological examination, it was not possible to establish an accurate diagnosis. Immunophenotyping, using a panel for chronic lymphoproliferations, allows accurate and precise diagnosis in a high percentage of these diseases. In some cases, a differential diagnostic exclusion of a chronic lymphoproliferative disease is very important and the possibility of directing the diagnosis in a particular direction, for example, to acute leukemia, $\mathrm{T}$ and NK lymphoproliferations, or to establish a normal B cell phenotype. Significance of the cooperation of the hematologist with the cytometry laboratory was also pointed out.

\section{Reference}

1. Swerdlow SH, Campo E, Haris NL, Jaffe E S, Pileri SA,Stein H,Thiele J,Vardiman J (eds).WHO Classification of Tumors of Haematoietic and Lymphoid Tissues. IARC:Lyon 2008

2. Matutes E, Wotherspoon A,Catovsky D. Differential diagnosis in chronic lymphocytic leukemia. Best Pract Res Clin Haematol 2007; 20(3):367-384.

https://doi.org/10.1016/j.beha.2007.03.001 PMid:17707827

3. Matutes E, Owusu-Ankomah K, Morilla R, et al. The immunological profile of $\mathrm{B}$ cell disorders and proposal of a scoring system for the diagnosis of CLL. Leukemia 1994;8:1640-1645. PMid:7523797

4. Moreau EJ, Matutes E, A'Hern RP,et al. Improvement of the chronic lymphocytic leukemia scoring system with the monoclonal antibody SN8 (CD79b). Am J Clin Pathol 1997;108:378-382.

https://doi.org/10.1093/ajcp/108.4.378

PMid:9322589

5. Matutes E, PolliackA. Morphological and immunofenotypic features of chronic lymphocytic leukemia. Rev Clin Exp Hematol 2000;4(1): 22-47.

https://doi.org/10.1046/j.1468-0734.2000.00002.x PMid:11486329

6. Asaad NY, Abd El-Wahed MM, Dawoud MM. Diagnosis and prognosis of B-Cell chronic lymphocytic leukemia/ small lymphocytic lymphoma (B-CLL/SLL) and Mantle cell lymphoma(MCL). J Egypt Natl Canc Inst 2005; 17(4): 279-290 PMid:17102815

7. Stetler-Stevenson M, Tembhare PR. Diagnosis of hairy cell leukemia by flow cytometry. Leuk Lymphoma 2011 jun ; 52 Suppl 2:11-3 Epub 2011 April 19.Available at: https://www.ncbi.nlm.nih.gov/pubmed/21504292 (accessed Dec 25,2016).

https://doi.org/10.3109/10428194.2011.570820 PMID: 21504292

8. Bacal N S, Mantvani E, Grosl S, et al. Flow Cytomery: Immunophenotyping in 48 hairy cell leukemia cases and relevance of fluotrscence intensity in CDs expression for diagnosis. Einstein 2007; 5(2):123-128

9. Matutes E. New additions to antibbody panels in the caracterisations of chronic lymphoproliferative disorders. 
J Clin Pathol 2002;55(3):180-184

https://doi.org/10.1136/jcp.55.3.180

PMid:11896067

PMCid:PMC1769604

10. Vose JM. Mantle cell lymphoma; update on diagnosis, risk stratification and clinical management. Am J Hematol 2015;90 (8) 739-745. https://doi.org/10.1002/ajh.24094

PMid:26103436

11. Rozman C,Montserrat E. Chronic Lymphocytic leukemia. N Engl J Med 1995; 333: 1052-1057 https://doi.org/10.1056/NEJM199510193331606 PMid:7675049

\section{Značaj protočne citometrije u dijagnostici hroničnih limfoproliferativnih oboljenja}

\section{SAŽETAK}

Uvod: Neoplazme zrelih B ćelija predstavljaju 90\% svih limfoidnih neoplazmi i 4\% novootkrivenih karcinoma godišnje. Uz ispitivanje morfologije ćelija, imunofenotipizacija protočnom citometrijom je esencijalna u dijagnostici ovih oboljenja.

Cilj rada: Ispitati stepen saglasnosti uputnih dijagnoza sa rezultatima imunofenotipizacije kod pacijenata pod sumnjom da su oboljeli od hroničnih limfoproliferativnih bolesti.

Ispitanici i metode: Ispitivanjem je obuhvaćeno 125 pacijenata podijeljenih prema uputnim dijagnozama u tri grupe: CLL, $\mathrm{NHL}$ i ostalo (opisne dijagnoze). Uzorak je periferna krv sa K2EDTA, diluirana fofatnim puferom i inkubirana sa odgovarajućom kombinacijom fluorohromima konjugovanih monoklonskih antitijela. Primjenjen je 4-color panel antitijela za B hronične limfoproliferacije. Analiza je urađena na protočnom citometru FACS Canto II, DIVA software.

Rezultati: U prve dvije grupe, kod 72,9\% pacijenata, uputna dijagnoza je odgovarala rezultatu imunofenotipizacije, 19,8\% bi bilo pogrešno klasifikovano bez ispitivanja imunofenotipa, a za 7,3\% je preporučena dodatna obrada. U grupi "ostalo" se bez imunofenotipizacije ne bi mogla postaviti dijagnoza. 12 uzoraka nije pripadalo grupi hroničnih B limfoproliferacija, a kod 8 je nađen normalan B ćelijski fenotip.

Zaključak: Klinička ispitivanja i morfologija ćelija su često nespecifični i nedovoljni za postavljanje dijagnoze hroničnih limfoproliferativnih oboljenja. Primjenom protočne citometrije, izbjegnuto je postavljanje pogrešne dijagnoze i neadekvatna terapija kod značajnog broja pacijenata, ali i omogućeno dijagnostifikovanje kod onih sa radnim, opisnim dijagnozama. $U$ nekim slučajevima značajno je diferencijalno dijagnostičko isključenje hronične limfoproliferativne bolesti i mogućnost da se dijagnoza usmjeri u određenom pravcu, npr. prema akutnim leukemijama, T i NK limfoproliferacijama ili da se utvrdi normalan B ćelijski fenotip.

Ključne riječi: Protočna citometrija, imunofenotip, panel monoklonskih antitijela, B hronična limfoproliferativna oboljenja 